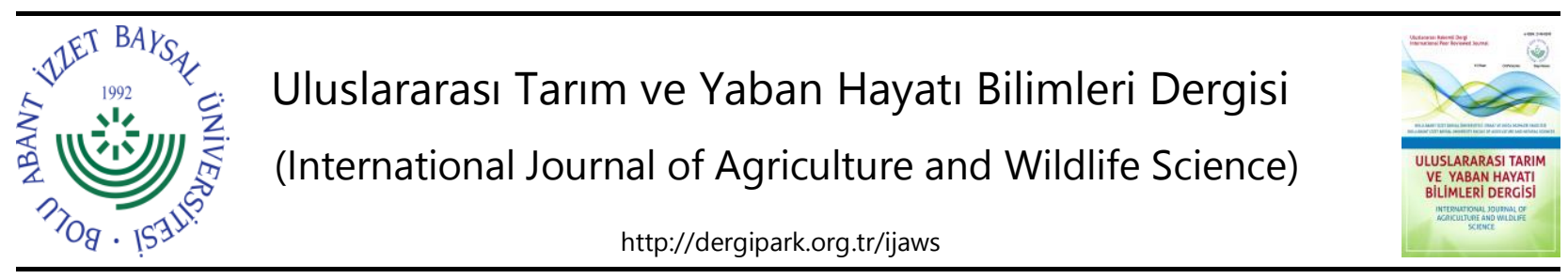

Araştırma Makalesi

\title{
Farklı Zamanlarda Ekilen Bazı Yem Bezelyesi (Pisum sativum ssp.arvense L.) Çeşitlerinin Tohum ve Kesinin Besin Değerleri
}

\author{
Bilal Keskin $^{1 *}$ (D) , Süleyman Temel ${ }^{1}$ (D) $\quad$ Barış Eren $^{2}$ \\ ${ }^{1}$ Iğdır Üniversitesi Ziraat Fakültesi Tarla Bitkileri Bölümü, lğdır \\ ${ }^{2}$ Iğdır Üniversitesi Ziraat Fakültesi Tarımsal Biyoteknoloji Bölümü, Iğdır \\ Geliş tarihi (Received): 29.01.2021～Kabul tarihi (Accepted): 11.03.2021
}

\begin{abstract}
Anahtar kelimeler:
Yem bezelyesi, ekim zamanı,

çeşit, yem kalitesi, tohum, kes
\end{abstract}

Özet. Bu araştırma Iğdır ekolojik şartlarında kışlık ve yazlık olmak üzere 6 farklı ekim zamanı (Ekim sonu Kasım başı ve Kasım sonu, Mart başı, Mart sonu, Nisan başı)'nda, 4 farklı yem bezelyesi (GAP Pembesi, Kirazlı, Özkaynak ve Taşkent) çeşidinin tohum ve keslerinin yem olarak besin değerleri belirlenmiştir. Deneme Iğdır Üniversitesi Tarımsal Uygulama ve Araştırma Merkez Müdürlüğünün deneme sahasında 2018-2019 ve 2019-2020 yıllarında olmak üzere 2 yıl süreyle tesadüf bloklarında bölünmüş parseller deneme desenine göre 3 tekerrürlü olarak kurulmuştur. Araştırmada yem bezelyesi'nin tohumda ham protein oranı (tohum-HP), kes ham protein oranı (kes-HP kes nötr çözücülerde çözünemeyen lif (kes-NDF), asit çözücülerde çözünemeyen lif (kes-ADF), kuru madde sindirilebilirliği (kes-KMS), kuru madde tüketimi (kes-KMT), sindirilebilir enerji (kes-SE), metabolik enerji (kes-ME), ve nispi yem değeri (kes-NYD) belirlenmiştir. Araştırma sonuçlarına göre, tohumHP oranı, kes-HP oranı, kes NDF oranı, kes-ADF oranı, kes-KMT oranı ve kes-NYD değeri Nisan ayı başındaki ekimlerde en iyi değerlere ulaştığı görülmüştür. Çeşitler arasında ise en iyi yem değerleri Özkaynak çeşidinde belirlenmiştir. Araştırma sonuçlarına göre Iğdır ekolojik şartlarında yem bezelyesi yetiştiriciliğinde tohum ve kes en iyi yem değerlerinin alınabilmesi için Özkaynak çeşidinin ekilmesi gerekmektedir. Diğer taraftan Nisan başında yapılacak ekimlerde kes kalitesinin daha yüksek olacağı belirlenmiştir.

\section{Feed Values of Seed and Straw of Some Forage Pea (Pisum sativum ssp. arvense L.) Varieties at Different Sowing Times}

\section{Keywords:}

Forage pea, sowing time, variety, feed quality, seed, straw
Abstract. This research was conducted to determine nutritional values of seeds and straws of 4 different forage peas (GAP Pembesi, Kirazlı, Özkaynak and Taşkent) cultivars in 6 different sowing times (late October, early November and late November early March, late March, early April,) under the Iğdır ecological conditions. The research was established according to randomized complete block design in split plots with three replications in the experimental area of Iğdır University Agricultural Application and Research Center Directorate in 2018-2019 and 2019-2020 for 2 years. In the study, forage pea's crude protein ratio in seed (seed-CP), straw crude protein ratio (straw-CP), straw neutral detergent fiber (straw-NDF), acid detergent fiber (straw-ADF), dry matter digestibility (straw-DMD), dry matter intake (straw-DMI), digestible energy (straw-DE), metabolic energy (straw$\mathrm{ME}$ ), and relative feed value (straw-RFV) were determined. Seed-CP ratio, straw-CP ratio, straw-NDF ratio, straw-ADF ratio, straw-DMD and straw-RFV value have been found to reach the best values in early April sowing. Among the varieties, the best feed values were determined in the Özkaynak variety. According to the results of the research, it was determined that Özkaynak variety should be sown in early April in order to obtain the best feed values in seeds and straw in the ecological conditions of Iğdır. 


\section{GíRiş}

Türkiye'de 2018 yılı istatistiklerine göre yem bezelyesi toplam ekim alanı içerisinde \%0.05'lik bir paya sahiptir. Yıldan yıla ekim alanları hızla artan bir bitkidir. 2014 yılında 37.395 da alanda ekim yapılırken, 2018 yılında 104.377 da alanda ekim yapılmış olup, yem bezelyesinin ekim alanı 5 yılda yaklaşık 3 kat artış göstermiştir. (TÜiK, 2018). Iğdır ilinde ise yem bezelyesi ekim alanı henüz istatistiklere girecek kadar değildir.

Yem bezelyesi tohum üretimi, ot üretimi, silaj ve yeşil gübreleme amacıyla tek başına veya buğdaygil bitkileri ile karışım olarak ekilmektedir (ileri ve ark., 2020). Yem bezelyesi tohumları \%20-30 civarında ham protein içerirler ve bundan dolayı kesif yem olarak hayvan beslemede tercih edilen bir bitkidir (Avcıoğlu ve ark., 2009). Avrupa ülkelerinde yem bezelyesi tohumlarının protein içeriğinin yüksekliği nedeniyle soya bitkisine alternatif olarak tavsiye edilmektedir (Açıköz, 2001; Avcıoğlu ve ark., 2009). Yem bezelyesi tohum hasadından sonra geriye kalan kesi hayvan besleme amacıyla kullanılan tahıl samanlarından daha besleyici ve kalitelidir (Açıkgöz, 2001; Manga ve ark., 2003; Acar ve Ayan, 2012).

Yem bezelyesi çeşitlerinin yem kalite özellikleri birbirlerinden az çok farklılık gösterebilmektedir. Yapılan birçok çalışmada tohumların ham protein oranlarını (Uzun ve ark., 2012; Kaplan ve ark., 2014), kes ham protein oranları, kes NDF oranları, kes ADF oranları, kes KMS oranları ve kes KMT oranları çeşitler arasında önemli derecede farklıık gösterdiği belirlenmiştir (Çaçan ve ark., 2018). Yem bezelyesi kışları soğuk geçen bölgelerimizde kışlık olarak ekimi yapılarak yeterli miktarda ürün alınabilmektedir (Tekeli ve Ateş, 2003; Tan ve ark. 2013). Bölgelerin kış şartlarının birbirlerinden farklı olması ve sonbaharda ekimi yapılan yem bezelyesinin ne kadarlık bir gelişme göstermeleri halinde kış zararlarından korunmalarına katkı sağlayacağının bilinmesi gerekmektedir. İlkbahar ve sonbahar ekim zamanları bitkilerin verim ve kaliteleri üzerine etkileri olmaktadır (Uzun ve Açıkgöz, 1998; Kadığlu ve Tan, 2018). Serin mevsim ve uzun gün bitkisi olan yem bezelyesi yüksek sıcaklıklarda hızlıca vejetatif devreyi sonlandırarak generatif devreye geçmekte, bu durum verim ve kalite üzerine önemli etkileri olabilmektedir (Sheaffer ve Moncada, 2012; Shaukat ve ark. 2012; Mukherjee ve ark. 2013).

Bu çalışma Iğdır ekolojik şartlarında yem bezelyesi çeşitlerinin kışlık ve yazlık olmak üzere 6 ekim zamanındaki tohum ve kesinin bazı besin kalite özelliklerinin belirlenmesi amacıyla yapılmışır.

\section{MATERYAL VE METOT}

Araştırma; Iğdır Üniversitesi Tarımsal Uygulama ve Araştırma Merkezi deneme sahasında 2018-2019 ve 20192020 yıllarında yazlık ve kışlık olmak üzere 6 farklı ekim zamanı (Mart ayı başında, Mart ayı sonunda, Nisan ayı başında, Ekim ayı sonu, Kasım ayı başı ve Kasım ayı sonu)'nda 4 farklı yem bezelyesi (GAP Pembesi, Kirazı Özkaynak ve Taşkent) çeşidinin tohum ve kesinin hayvanların kullanımı açısından yem değerini belirlemek amacıyla yürütülmüştür. Araşıırmaya 2018 yılının Mart ayında başlanılmıştır. Sırasıyla 2018-2019 ve 2019-2020 yılları ilkbahar tohum ekimleri 07 ve 14 Mart, 22 ve 28 Mart, 06 ve 12 Nisan, sonbahar tohum ekimleri ise 22-22 Ekim, 12 ve 5 Kasım ve 22 ve 19 Kasım tarihlerinde yapılmıştır.

Denemenin yürütüldüğü yıllara ait bazı iklim değerleri Çizelge 1'de verilmiştir. Çizelge 1 incelendiğinde 20182019 yılarındaki sıcaklık $\left(15.1^{\circ} \mathrm{C}\right)$, yağış $(352.6 \mathrm{~mm})$ ve nem $(\% 58.3)$ daha yüksek olmuştur. Uzun yıllara göre, denemenin yürütüldüğü 2018-2019 ve 2019-2020 yıllarındaki sıcaklık ve nem miktarı yüksek, yağış miktarı ise düşük gerçekleşmiştir (Çizelge 1). Araştırmanın yürütüleceği bölge karasal iklim kuşağında yer almakla birlikte çevresindeki birçok bölgeye göre mikroklima özelliği göstermektedir. Yıllık yağış değerlerine bakıldığında ülkemizin en kurak bölgeleri arasında yer aldığı görülmektedir.

Çizelge 1. Araştırmanın yürütüldüğü bölgeye ait bazı iklim verileri (Anonim, 2020).

Table 1. Some climate data for the region where the research was conducted (Anonymous, 2020)

\begin{tabular}{|c|c|c|c|c|c|c|c|c|c|}
\hline \multirow[t]{2}{*}{ Aylar } & \multicolumn{3}{|c|}{ 2018-2019 yılı } & \multicolumn{3}{|c|}{ 2019-2020 yılı } & \multicolumn{3}{|c|}{ UYO (1978-2017) } \\
\hline & $\begin{array}{l}\text { Sicaklık } \\
\left({ }^{\circ} \mathrm{C}\right)\end{array}$ & $\begin{array}{l}\text { Yağış } \\
(\mathbf{m m})\end{array}$ & $\begin{array}{l}\text { Nem } \\
(\%)\end{array}$ & $\begin{array}{l}\text { Sicaklık } \\
\left({ }^{\circ} \mathrm{C}\right)\end{array}$ & $\begin{array}{l}\text { Yağış } \\
(\mathrm{mm})\end{array}$ & $\begin{array}{l}\text { Nem } \\
(\%)\end{array}$ & $\begin{array}{l}\text { Sicaklık } \\
\left({ }^{\circ} \mathrm{C}\right)\end{array}$ & $\begin{array}{l}\text { Yağış } \\
(\mathbf{m m})\end{array}$ & $\begin{array}{l}\text { Nem } \\
(\%)\end{array}$ \\
\hline Mart & 12.3 & 16.5 & 51.9 & 6.8 & 23.5 & 59.7 & 6.9 & 21.5 & 49.9 \\
\hline Nisan & 14.2 & 18.2 & 49.7 & 12.1 & 25.1 & 56.9 & 13.4 & 37.9 & 49.0 \\
\hline Mayıs & 18.4 & 69.1 & 65.5 & 19.9 & 25.9 & 51.2 & 17.6 & 48.9 & 51.1 \\
\hline Haziran & 23.4 & 31.8 & 54.5 & 25.6 & 13.6 & 45.8 & 22.3 & 33.2 & 45.7 \\
\hline Temmuz & 29.2 & 5.8 & 42.8 & 27.3 & 0.6 & 40.1 & 26.2 & 14.7 & 43.3 \\
\hline Ağustos & 26.4 & 4.1 & 48.4 & 27.0 & 0.6 & 41.2 & 25.6 & 9.8 & 44.5 \\
\hline Eylül & 22.8 & 6.5 & 48.2 & 20.0 & 10.5 & 53.6 & 20.7 & 10.3 & 48.9 \\
\hline Ekim & 15.0 & 20.8 & 63.9 & 15.8 & 4.5 & 58.0 & 13.3 & 28.1 & 62.3 \\
\hline
\end{tabular}


Çizelge 1. Devamı.

Table 1. Continue.

\begin{tabular}{|c|c|c|c|c|c|c|c|c|c|}
\hline \multirow[t]{2}{*}{ Aylar } & \multicolumn{3}{|c|}{ 2018-2019 yılı } & \multicolumn{3}{|c|}{ 2019-2020 yılı } & \multicolumn{3}{|c|}{ UYO (1978-2017) } \\
\hline & $\begin{array}{l}\text { Sicaklık } \\
\left({ }^{\circ} \mathrm{C}\right)\end{array}$ & $\begin{array}{l}\text { Yağış } \\
(\mathrm{mm})\end{array}$ & $\begin{array}{l}\text { Nem } \\
(\%)\end{array}$ & $\begin{array}{l}\text { Sicaklık } \\
\left({ }^{\circ} \mathrm{C}\right)\end{array}$ & $\begin{array}{l}\text { Yağış } \\
(\mathrm{mm})\end{array}$ & $\begin{array}{l}\text { Nem } \\
\text { (\%) }\end{array}$ & $\begin{array}{l}\text { Sicaklık } \\
\left({ }^{\circ} \mathrm{C}\right)\end{array}$ & $\begin{array}{l}\text { Yağış } \\
(\mathbf{m m})\end{array}$ & $\begin{array}{l}\text { Nem } \\
(\%)\end{array}$ \\
\hline Kasım & 7.0 & 29.4 & 80.9 & 4.3 & 8.0 & 70.1 & 5.9 & 19.4 & 65.7 \\
\hline Aralık & 3.9 & 30.9 & 81.6 & 4.7 & 8.2 & 80.0 & -0.4 & 13.0 & 68.4 \\
\hline Ocak & 0.6 & 12.3 & 69.3 & 0.0 & 7.3 & 65.2 & -3.1 & 13.1 & 66.5 \\
\hline Şubat & 3.7 & 19.1 & 61.9 & 1.9 & 14.1 & 64.5 & 0.3 & 15.5 & 59.8 \\
\hline Mart & 6.8 & 23.5 & 59.7 & 10.6 & 18.1 & 56.5 & 6.9 & 21.5 & 49.9 \\
\hline Nisan & 12.1 & 25.1 & 56.9 & 11.7 & 83.6 & 64.8 & 13.4 & 37.9 & 49.0 \\
\hline Mayıs & 19.9 & 25.9 & 51.2 & 18.6 & 76.1 & 55.0 & 17.6 & 48.9 & 51.1 \\
\hline Haziran & 25.6 & 13.6 & 45.8 & 23.9 & 15.7 & 44.7 & 22.3 & 33.2 & 45.7 \\
\hline Top./Ort. & 15.1 & 352.6 & 58.3 & 14.4 & 335.4 & 56.7 & 13.1 & 406.9 & 53.2 \\
\hline
\end{tabular}

UYO: Uzun yıllar ortalaması

Çizelge 2. Araştırmanın yürütüldüğü topraklara ait bazı özellikler.

Table 2. Some characteristics of the soils where the research was conducted.

\begin{tabular}{cccccccc}
\hline $\mathbf{p H}$ & Kireç & $\begin{array}{c}\text { EC } \\
\text { \% }\end{array}$ & $\begin{array}{c}\text { Organik Madde } \\
\text { (m) } \mathbf{c m})\end{array}$ & $\begin{array}{c}\mathbf{P} \\
(\mathbf{p p m})\end{array}$ & $\begin{array}{c}\mathbf{K} \\
(\mathbf{p p m})\end{array}$ & $\begin{array}{c}\mathbf{C a} \\
(\mathbf{p p m})\end{array}$ & $\begin{array}{c}\mathbf{M g} \\
(\mathbf{p p m})\end{array}$ \\
\hline $\mathbf{8 , 1 6}$ & 11,2 & 1.58 & 0.95 & 3.21 & 1.92 & 20 & 7.82 \\
\hline
\end{tabular}

Çizelge 2'de deneme alanının bazı toprak özellikler verilmiştir. Bu verilere göre deneme yapılan alanın topraklarının organik madde içeriği düşük, orta derecede alkali, az tuzlu, kireç içeriği yüksek olduğu görülmektedir.

Deneme sulu koşullarda tesadüf bloklarında bölünmüş parseller deneme desenine göre üç tekerrürlü olarak kurulmuş ve iki yıl süreyle yürütülmüştür. Denemede ana parsellere ekim zamanları, alt parsellere ise çeşitler yerleştirilmiştir. Her bir parsel $3 \mathrm{~m}$ uzunluğunda ve $1.75 \mathrm{~m}$ eninde olmak üzere toplam parsel alanı $5.25 \mathrm{~m}^{2}$ olarak ayarlanmıştır. Denemede parseller arası $1.2 \mathrm{~m}$, bloklar arası $1.5 \mathrm{~m}$ ve ana parseller arası $2 \mathrm{~m}$ boşluk bırakılmıştır. Bir yıllık sure içerisinde 6 ekim zamanı $\times 4$ çeşit $\times 3$ tekerrür olmak üzere toplamda 72 parsel ekimi yapılmıştır. Tohumlar $35 \mathrm{~cm}$ sıra aralığında ve $10 \mathrm{~cm}$ sıra üzeri el markörü ile açılan tohum yataklarına $4 \mathrm{~cm}$ derinliğe gelecek şekilde elle ekilmişlerdir. Ekimle birlikte yem bezelyesine dekara $5 \mathrm{~kg}$ saf azot (\%21'lik amonyum sülfat gübresinden) ve $12 \mathrm{~kg}$ saf fosfor (\%39-41'lik Triple Süper fosfat gübresinden) kullanılmıştır.

Bitkiler toprak yüzeyine çıktıktan sonra su ihtiyaçları Tarımsal Uygulama ve Araştırma Merkez sahasında $76 \mathrm{~m}$ derinlikten çıkarılan ve sulama için uygun olan kuyu sulu ile yağmurlama sulama yöntemi kullanılarak yapılmıştır. Bitkiler çiçek oluşturmaya başladıktan sonra sulamalar salma sulama yöntemi ile yapılmıştır. Parsel içerisi ve parsel aralarında gelişme gösteren yabancı otlarla el çapası ve çapa makinesi ile mücadelesi yapılmıştır. Tohum hasatları baklaların olgunlaşıp dolduğu ve tohumların sertleştiği dönemde yapılmıştır.

Elde edilen tohum ve kes örnekleri $70^{\circ} \mathrm{C}$ ayarlı etüvde ağırlıkları sabitleşinceye kadar kurutulmuş ve öğütme değirmeninde öğütülmüştür. Mikro Kjeldahl metoduna göre toplam azot tayinleri yapılmıştır. Azot oranları 6.25 katsayısı ile çarpılarak ham protein oranları belirlenmiştir (Akyıldız, 1984; Kacar ve İnal, 2008). Yem bezelyesi tohumları harmanlandıktan sonra tohumları ayıklanmış ve geriye kalan tüm bitki kısımları kurutulup öğütülmüştür. Sonra örnek materyaller hassas terazi yardımıyla Filterbag içerisine toplam ağırlık $0.950 \mathrm{~g}-1.050 \mathrm{~g}$ olacak şekilde tartım işlemleri yapılmıştır. Daha sonra Ankom Fiber analiz cihazında NDF ve ADF oranıları Van Soest et al. (1991) tarafından geliştirilen metot kullanılarak belirlenmiştir. Kuru madde sindirilebilirliği Sheaffer et al. (1995) tarafından önerilen KMS = $88.9-(0.779$ × \%ADF) formülüne göre hesaplanmıştır. Kuru madde tüketimi (Sheaffer et al. 1995) tarafından önerilen Kuru Madde Tüketimi $(K M T)=120$ / (\%NDF) formülüne göre hesaplanmıştır. Sindirilebilir enerji (SE) Fonnesbeck et al. (1984) tarafından önerilen SE (Mcal kg-1) $=0.27+0.0428 \times(\% \mathrm{KMS})$ formülüne göre hesaplanmıştır. Metabolik enerji ME (Mcal kg $\left.{ }^{-1}\right)=0.821 \times S E$ formülüne göre hesaplanmıştır (Khalil et al., 1986). NDF ve ADF analiz sonucu elde edilen değerlerden faydalanılarak Sheaffer et al. (1995) tarafından geliştirilen NYD $=($ KMSXKMT $) / 1.29$ formülüne göre NYD değerleri belirlenmiştir.

Araştırmada elde edilen veriler JMP 5.0.1 istatistik paket programı kullanılarak tekrarlanan (Yıl) bölünmüş parseller deneme desenine göre varyans analizleri ve önemli çıkan ortalamaların karşılaştırmaları ise LSD testine göre yapılmıştır (Yıldız ve Bircan, 1991). 


\section{BULGULAR VE TARTIŞMA}

\section{Tohumda Ham Protein Oranı}

Tohumda ham protein oranına yılların etkisi önemsiz olurken, ekim zamanı ve çeşitlerin etkisi önemli olmuştur. En yüksek tohumda ham protein oranı \%24.52 ile Nisan ayı başında yapılan ekimlerde, en düşük tohum ham protein oranı ise \%21.42 ve \%21.53 ile sırasıyla Mart ayı başında (EZ-1) ve Ekim ayı sonu (EZ-4)'nda elde edilmiştir. Çeşitler arasında tohum ham protein oranları \%21.46 ile \%24.67 arasında değişmiştir. En yüksek tohum ham protein oranı \%24.67 ile Özkaynak çeşidinde, en düşük tohum ham protein oranı \%21.46 ile Kirazlı çeşidinde belirlenmiştir. Yapılan araştırmalar yem bezelyesi tohumlarının ham protein oranlarını çeşitlere göre önemli miktarda değiştiğini ve çeşitlerin tohum ham protein oranının \%20.2 ile \%22.5 (Uzun ve ark., 2012) ve \%20.39 ile \%31.63 (Kaplan ve ark., 2014) arasında değiştiğini belirlemişlerdir (Çizelge 3).

Çizelge 3. Yıl, Ekim zamanı ve çeşitlere göre yem bezelyesinin tohum HP oranı ve kes HP oranı.

Table 3. Seed CP ratio and straw CP ratio of forage pea according to year, sowing time and varieties.

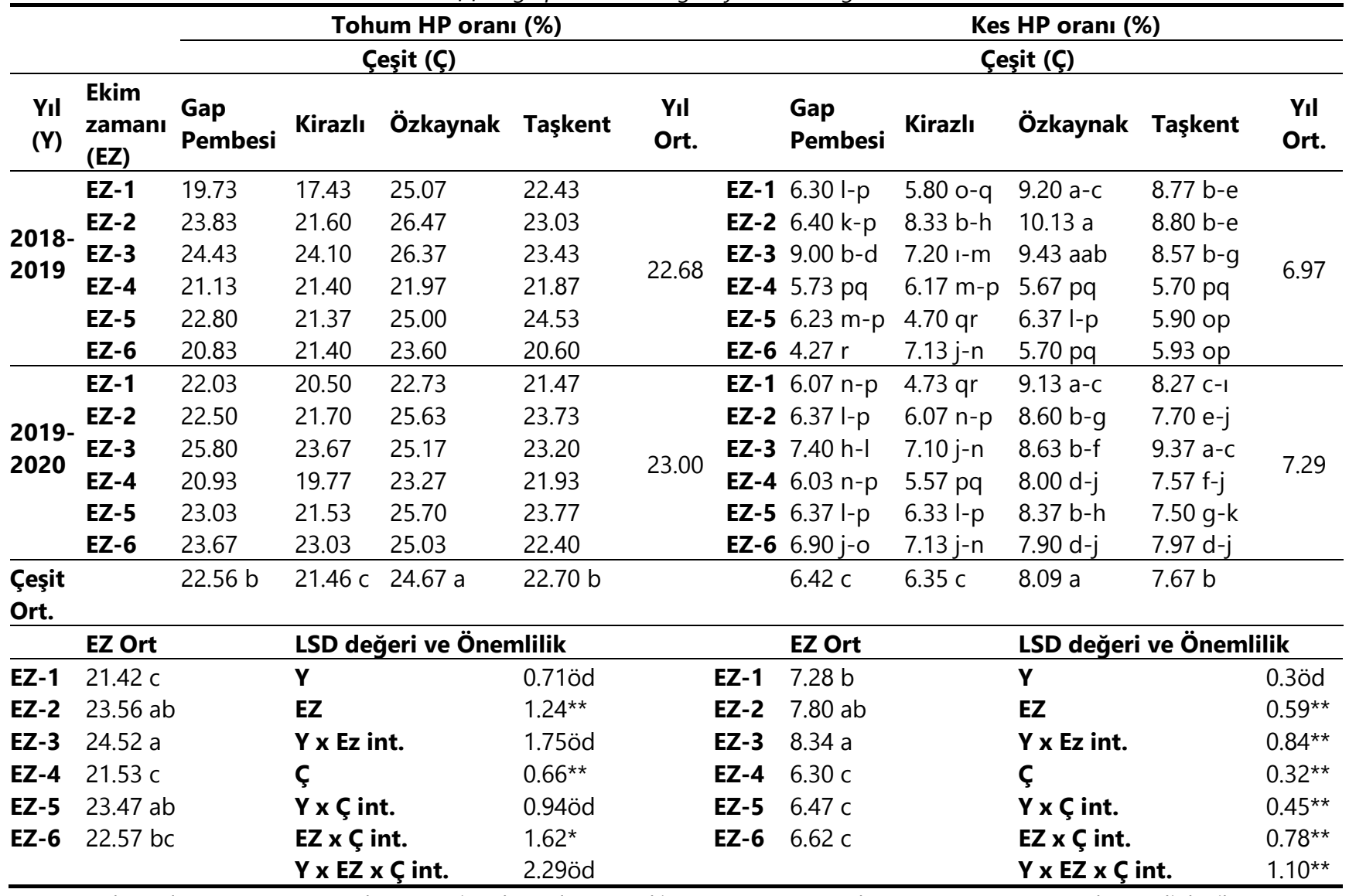

EZ-1: Mart başında, EZ-2: Mart sonunda, EZ-3: Nisan başında, EZ-4: Ekim sonu, EZ-5: Kasım başı, EZ-6: Kasım sonu, öd: önemli değil, **: P>0.01, *: P>0.05, aynı harflerle gösterilen veriler arasında fark istatistiksel olarak önemli değildir.

\section{Kes Ham Protein Oranı}

Kes ham protein oranına yılların etkisi önemsiz olurken, ekim zamanı ve çeşitlerin etkisi önemli olmuştur. En yüksek kes ham protein oranı \%8.34 ile Nisan ayı başında (EZ-3) yapılan ekimlerde, en düşük kes ham protein oranı ise \%6.30, \%6.47 ve \%6.62 ile sonbaharda EZ-4, EZ-5 ve EZ-6'da elde edilmiştir. Çeşitler arasında kes ham protein oranları \%6.35 ile \%8.09 arasında değişmiştir. En yüksek kes ham protein oranı \%8.09 ile Özkaynak çeşidinde, en düşük kes ham protein oranı \%6.35 ve \%6.42 ile sırasıyla Kirazlı ve Gap Pembesi çeşitlerinde tespit edilmiştir. Yıl, ekim zamanı ve çeşitlerin birlikte etkileri sonucu kes ham protein oranları \%4.27 ile \%10.13 arasında değişmiştir. En yüksek kes ham protein oranı \%10.13 ile 2018 yılında Mart ayı sonunda (EZ-2) ekilen Özkaynak çeşidinde, en düşük kes ham protein oranı \%4.27 ile 2018 yılında Kasım ayı sonunda (EZ-6) ekilen Gap Pembesi çeşidinde elde edilmiştir (Çizelge 3).

Yem bezelyesinin 14 çeşidi ile yapılan bir araştırmada çeşitlerin kes ham protein oranları (\%6.54 ile \%11.91) arasında önemli farklar olduğu, diğer taraftan kes ham protein oranı üzerine yılların etkisinin olmadığı belirlenmiş̧tir (Çaçan ve ark., 2018). 


\section{Kes NDF Orant}

Kes NDF oranı üzerine ekim zamanları ve çeşitlerin etkisi önemli bulunurken, yılların etkisi önemsiz olmuştur. Sonbahar ekimlerinde (EZ-4, EZ-5 ve EZ-6) kes NDF oranı yüksek, Illkbahar ekimlerinde (EZ-1, EZ-2, EZ-3) ise kes NDF oranları düşük olmuştur. En düşük kes NDF oranı \%50.4 ile Nisan ayı başında (EZ-3) ekimi yapılan yem bezelyelerinde tespit edilmiştir. Gap Pembesi, Özkaynak ve Taşkent çeşitlerinin kes NDF oranları arasında benzerlik olmuş ve Kirazlı çeşidine göre daha düşük kes NDF değerleri elde edilmiştir. Yıl ekim zamanı ve çeşitlere göre kes NDF oranları \%46.5 ile \%62.5 arasında değişmiştir (Çizelge 4).

Yapılan bir araştırmada yem bezelyesi kes NDF oranı yıllara ve çeşitlere göre önemli derecede etkilenmiştir. Yem bezelyesi çeşitlerinin kes NDF oranları \%39.1 ile \%51.2 arasında değiştiği tespit edilmiştir (Çaçan ve ark., 2018).

Çizelge 4. Yıl, Ekim zamanı ve çeşitlere göre yem bezelyesinin kes NDF oranı ve kes ADF oranı.

Table 4. Straw NDF ratio and straw ADF ratio of forage pea according to year, sowing time and varieties.

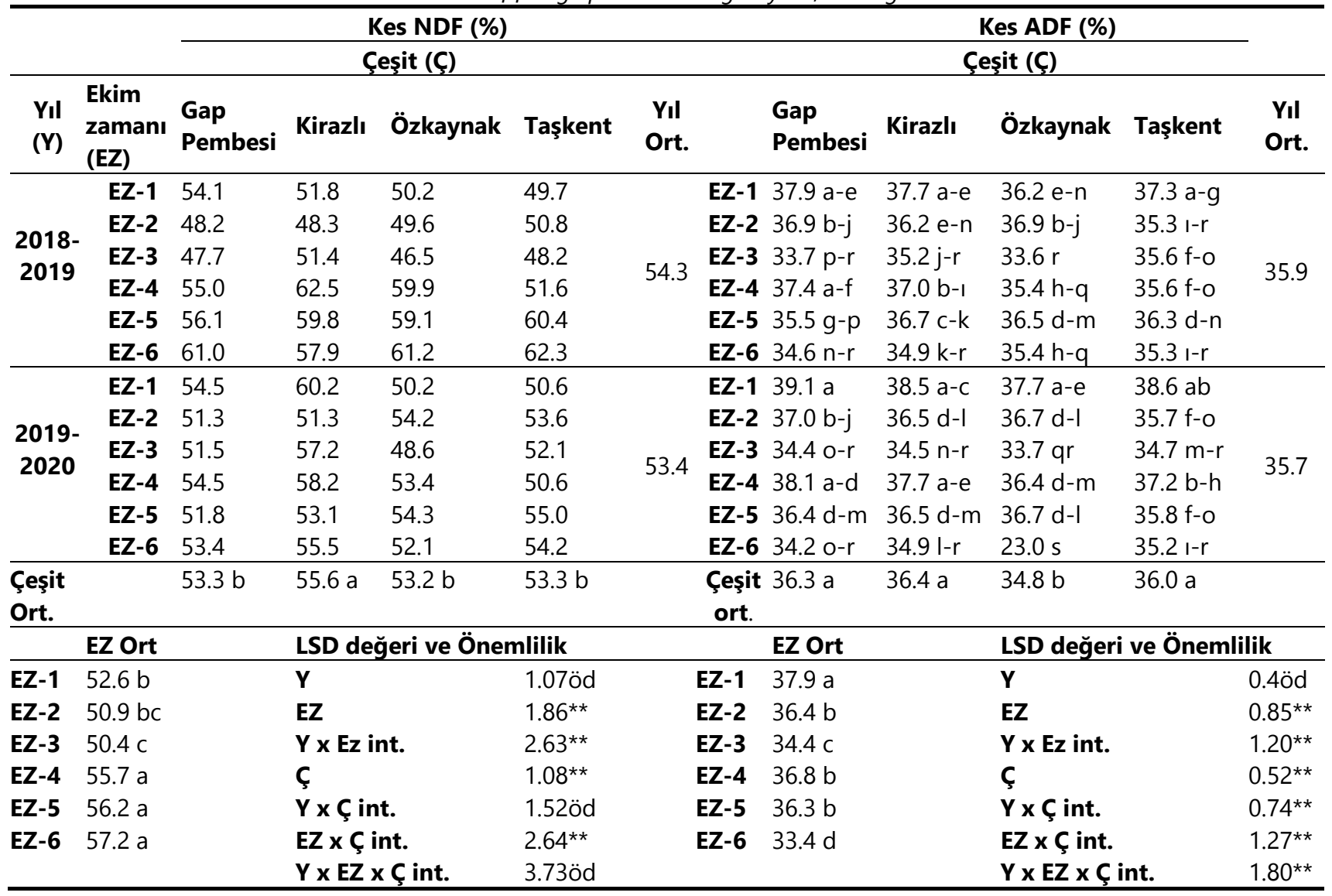

EZ-1: Mart başında, EZ-2: Mart sonunda, EZ-3: Nisan başında, EZ-4: Ekim sonu, EZ-5: Kasım başı, EZ-6: Kasım sonu, öd: önemli değil, **: P>0.01 *: $P>0.05$, aynı harflerle gösterilen veriler arasında fark istatistiksel olarak önemli değildir.

\section{Kes ADF Oranı}

Kes ADF oranı üzerine ekim zamanları ve çeşitlerin etkisi önemli bulunurken, yılların etkisi önemsiz olmuştur. En düşük kes ADF oranı \%33.4 ile Kasım ayı sonu (EZ-6) ekilen yem bezelyelerinde, en yüksek kes ADF oranı ise \%37.9 ile mart ayı başında (EZ-1) ekilen yem bezelyelerinde belirlenmiştir. Çeşitler arasında en düşük kes ADF oranı \%34.8 ile Özkaynak çeşidinde tespit edilmiş olup, diğer çeşitlerin (Gap Pembesi, Kirazlı ve Taşkent) kes ADF oranlarının daha yüksek olduğu belirlenmiştir (Çizelge 4).

Yıl, ekim zamanı ve çeşitlerin birlikte etkileri sonucu kes ADF oranları \%33.6 ile \%39.1 arasında değişmiştir. En düşük kes ADF oranı \%33.6 ile 2018 yılında Nisan ayı başında (EZ-3) ekilen Özkaynak çeşidinde, en yüksek kes ADF oranı ise \%39.1 ile 2019 yılında Mart ayı başında (EZ-1) ekilen Gap Pembesi çeşidinde elde edilmiştir.

Yapılan bir araştırmada yem bezelyesi kes ADF oranı yıllara ve çeşitlere göre önemli derecede etkilenmiştir. Yem bezelyesi çeşitlerinin kes ADF oranları \%30.2 ile \%39.8 arasında değiştiği tespit edilmiştir (Çaçan ve ark., 2018). 


\section{Kes KMS Oranı}

Kes KMS oranına yılların etkisi önemsiz olurken, ekim zamanı ve çeşitlerin etkisi önemli olmuştur. En yüksek kes KMS oranı \%62.9 ile Kasım ayı sonunda (EZ-6) yapılan ekimlerde, en düşük kes KMS oranı ise \%60.1, \%60.5 ve \%60.6 ile sırasıyla EZ-4, EZ-5 ve EZ-2'de elde edilmiştir. Çeşitler arasında kes KMS oranları \%60.6 ile \%61.8 arasında değişmiş̧ir. En yüksek kes KMS oranı \%61.8 ile Özkaynak çeşidinde, en düşük kes KMS oranları ise \%60.6, \%60.7 ve \%60.8 ile sırasıyla Kirazlı, Gap Pembesi ve Taşkent çeşitlerinde tespit edilmiştir (Çizelge 5).

Yıl, ekim zamanı ve çeşitlerin birlikte etkileri sonucu kes KMS oranları \%58.5 ile \%71.0 arasında değişmiştir. En yüksek kes KMS oranı \%71.0 ile 2019 yılında Kasım ayı sonunda (EZ-6) ekilen Özkaynak çeşidinde, en düşük kes KMS oranı \%58.5 ile 2019 yılında Mart ayı başında (EZ-1) ekilen Gap Pembesi çeşidinde elde edilmiştir.

Yapılan bir araştırmada yem bezelyesi kes KMS oranı yıllara ve çeşitlere göre önemli derecede etkilenmiştir. Yem bezelyesi çeşitlerinin kes KMS oranları \%57.9 ile \%65.9 arasında değiştiği tespit edilmiştir (Çaçan ve ark., 2018).

Çizelge 5. Yıl, Ekim zamanı ve çeşitlere göre yem bezelyesinin kes KMS oranı ve kes KMT oranı.

Table 5. Straw DMD ratio of forage pea and straw DMI ratio by year, sowing time and varieties.

\begin{tabular}{|c|c|c|c|c|c|c|c|c|c|c|c|c|}
\hline \multirow[b]{3}{*}{$\begin{array}{l}\text { Yıl } \\
(Y)\end{array}$} & \multirow[b]{3}{*}{$\begin{array}{l}\text { Ekim } \\
\text { zamanı } \\
\text { (EZ) }\end{array}$} & \multicolumn{6}{|c|}{ Kes KMS (\%) } & \multicolumn{5}{|c|}{ Kes KMT (\%) } \\
\hline & & \multicolumn{5}{|c|}{ Çeşit (Ç) } & & \multicolumn{5}{|c|}{ Çeşit (Ç) } \\
\hline & & $\begin{array}{l}\text { Gap } \\
\text { Pembesi }\end{array}$ & Kirazlı & Özkaynak & Taşkent & $\begin{array}{l}\text { Yıl } \\
\text { Ort. }\end{array}$ & & $\begin{array}{l}\text { Gap } \\
\text { Pembesi }\end{array}$ & Kirazlı & Özkaynak & Taşkent & $\begin{array}{l}\text { Yil } \\
\text { Ort. }\end{array}$ \\
\hline \multirow{6}{*}{$\begin{array}{l}2018 \\
2019\end{array}$} & EZ-1 & $59.3 n-r$ & $59.5 \mathrm{~m}-\mathrm{r}$ & 60.7 e-n & $59.9 k-r$ & \multirow{6}{*}{60.8} & $E Z-1$ & 2.22 & 2.32 & 2.39 & 2.41 & \multirow{6}{*}{2.23} \\
\hline & EZ-2 & $60.1 \mathrm{~h}-\mathrm{q}$ & 60.7 e-m & $60.2 \mathrm{~h}-\mathrm{q}$ & $61.4 b-1$ & & EZ-2 & 2.50 & 2.48 & 2.42 & 2.37 & \\
\hline & EZ-3 & $62.7 \mathrm{bc}$ & $61.5 b-h$ & $62.7 \mathrm{~b}$ & $61.2 \mathrm{~d}-\mathrm{k}$ & & EZ-3 & 2.51 & 2.34 & 2.59 & 2.49 & \\
\hline & EZ-4 & $59.81-r$ & $60.11-q$ & $61.3 c-1$ & $61.2 \mathrm{~d}-\mathrm{k}$ & & $E Z-4$ & 2.20 & 1.90 & 2.00 & 2.37 & \\
\hline & EZ-5 & $61.3 d-j$ & $60.3 \mathrm{~h}-\mathrm{p}$ & $60.5 \mathrm{f}-\mathrm{o}$ & $60.6 e-n$ & & EZ-5 & 2.13 & 2.00 & 2.03 & 1.97 & \\
\hline & EZ-6 & $62.0 \mathrm{~b}-\mathrm{e}$ & $61.7 \mathrm{~b}-\mathrm{g}$ & $61.3 c-j$ & $61.4 \mathrm{~b}-1$ & & EZ-6 & 1.97 & 2.10 & 1.97 & 1.93 & \\
\hline \multirow{6}{*}{$\begin{array}{l}2019 \\
2020\end{array}$} & $E Z-1$ & $58.5 r$ & $58.9 p-r$ & $59.5 \mathrm{~m}-\mathrm{r}$ & $58.8 \mathrm{qr}$ & \multirow{6}{*}{61.0} & $E Z-1$ & 2.20 & 2.00 & 2.40 & 2.37 & \multirow{6}{*}{2.25} \\
\hline & EZ-2 & $60.11-q$ & $60.4 \mathrm{f}-\mathrm{o}$ & $60.3 \mathrm{~g}-\mathrm{O}$ & $61.0 d-1$ & & EZ-2 & 2.33 & 2.33 & 2.20 & 2.23 & \\
\hline & EZ-3 & $62.1 \mathrm{~b}-\mathrm{d}$ & $62.0 \mathrm{~b}-\mathrm{e}$ & $62.7 \mathrm{bc}$ & 61.9 b-e & & EZ-3 & 2.33 & 2.10 & 2.47 & 2.30 & \\
\hline & EZ-4 & 59.2 or & $59.5 \mathrm{~m}-\mathrm{r}$ & $60.5 \mathrm{f}-\mathrm{o}$ & $59.9 j-q$ & & EZ-4 & 2.20 & 2.07 & 2.23 & 2.33 & \\
\hline & EZ-5 & $60.5 \mathrm{f}-\mathrm{o}$ & $60.5 \mathrm{f}-\mathrm{o}$ & $60.3 \mathrm{~g}-\mathrm{o}$ & $61.0 \mathrm{~d}-1$ & & EZ-5 & 2.33 & 2.27 & 2.20 & 2.20 & \\
\hline & EZ-6 & $62.3 \mathrm{~b}-\mathrm{d}$ & $61.7 b-f$ & $71.0 \mathrm{a}$ & $61.5 b-h$ & & EZ-6 & 2.27 & 2.17 & 2.33 & 2.23 & \\
\hline \multirow[t]{2}{*}{$\begin{array}{l}\text { Çeşit } \\
\text { Ort. }\end{array}$} & & $60.7 \mathrm{~b}$ & $60.6 \mathrm{~b}$ & $61.8 \mathrm{a}$ & $60.8 \mathrm{~b}$ & & $\begin{array}{l}\text { Çeşit } \\
\text { ort. }\end{array}$ & $2.26 \mathrm{a}$ & $2.17 \mathrm{~b}$ & $2.26 \mathrm{a}$ & $2.26 \mathrm{a}$ & \\
\hline & \multicolumn{2}{|l|}{ EZ Ort } & \multicolumn{5}{|c|}{ LSD değeri ve Önemlilik } & EZ Ort & & \multicolumn{3}{|c|}{ LSD değeri ve Önemlilik } \\
\hline EZ-1 & \multicolumn{2}{|l|}{$59.4 d$} & \multicolumn{2}{|c|}{$\mathbf{Y}$} & \multicolumn{2}{|l|}{0.38 öd } & $E Z-1$ & \multicolumn{2}{|l|}{$2.28 \mathrm{~b}$} & $\mathbf{Y}$ & \multicolumn{2}{|c|}{0.05 öd } \\
\hline EZ-2 & \multicolumn{2}{|l|}{$60.5 c$} & \multicolumn{2}{|l|}{ EZ } & \multicolumn{2}{|l|}{$0.66^{* *}$} & EZ-2 & \multicolumn{2}{|l|}{$2.35 \mathrm{ab}$} & EZ & \multicolumn{2}{|c|}{$0.08^{* *}$} \\
\hline EZ-3 & \multicolumn{2}{|l|}{$62.1 \mathrm{~b}$} & \multicolumn{2}{|c|}{$Y \times$ Ez int. } & \multicolumn{2}{|l|}{$0.94^{* *}$} & EZ-3 & \multicolumn{2}{|l|}{$2.39 \mathrm{a}$} & $Y \times$ Ez int. & \multicolumn{2}{|c|}{$0.12^{\star *}$} \\
\hline EZ-4 & $60.1 \mathrm{c}$ & & Ç & & $0.40^{* *}$ & & $E Z-4$ & $2.16 \mathrm{c}$ & & Ç & $0.05^{\star}$ & \\
\hline EZ-5 & $60.6 c$ & & Y x Ç int. & & $0.57^{\star \star}$ & & EZ-5 & $2.14 \mathrm{c}$ & & Y x Ç int. & 0.07ة & \\
\hline EZ-6 & $62.9 \mathrm{a}$ & & $\begin{array}{l}E Z \times C ̧ \text { int } \\
Y \times E Z \times C\end{array}$ & int. & $\begin{array}{l}0.99^{* \star} \\
1.40^{* \star}\end{array}$ & & EZ-6 & $2.12 \mathrm{c}$ & & $\begin{array}{l}\text { EZ x Ç int. } \\
\text { YxEZ x C int. }\end{array}$ & $\begin{array}{l}0.12^{*} \\
0.170 ̈\end{array}$ & \\
\hline
\end{tabular}

EZ-1: Mart başında, EZ-2: Mart sonunda, EZ-3: Nisan başında, EZ-4: Ekim sonu, EZ-5: Kasım başı, EZ-6: Kasım sonu, öd: önemli değil, **: P>0.01 *: P>0.05, aynı harflerle gösterilen veriler arasında fark istatistiksel olarak önemli değildir.

\section{Kes KMT Oranı}

Kes KMT oranı üzerine ekim zamanları ve çeşitlerin etkisi önemli bulunurken, yılların etkisi önemsiz olmuştur. Sonbahar ekimlerinde (EZ-4, EZ-5 ve EZ-6) kes KMT oranı düşük, IIlkbahar ekimlerinde (EZ-1, EZ-2, EZ-3) ise kes KMT oranları yüksek olmuştur. En yüksek kes KMT oranı \%2.39 ile Nisan ayı başında (EZ-3) ekimi yapılan yem bezelyelerinde tespit edilmiştir. Yem bezelyesi çeşitleri arasında kes KMT oranları farklılık göstermiştir. Çeşitler arasında kes KMT oranları \%2.17 ile \%2.26 arasında değişmiştir. Gap Pembesi, Özkaynak ve Taşkent çeşitlerinin kes KMT oranları birbirine yakın değerlerde elde edilmiş ve Kirazlı çeşidine göre daha yüksek kes KMT oranlarına sahip olmuşlardır (Çizelge 5).

Yapılan bir araştırmada yem bezelyesi kes KMT oranı yıllara ve çeşitlere göre önemli derecede etkilenmiştir. Yem bezelyesi çeşitlerinin kes KMT oranları \%2.35 ile \%3.08 arasında değiştiği tespit edilmiştir (Çaçan ve ark., 2018). 


\section{Kes SE Miktarı}

Kes SE miktarı üzerine yılların etkisi önemli olmamıştır. Araştırmanın birinci yılındaki (2018 yılı) kes SE miktarı 2.87 Mcal kg-1, ikinci yıldaki (2019 yılı) kes SE miktarı $2.88 \mathrm{Mcal} \mathrm{kg}^{-1}$ olmuştur (Çizelge 6).

Ekim zamanlarına göre kes SE miktarı $2.81 \mathrm{Mcal} \mathrm{kg}^{-1}$ ile $2.95 \mathrm{Mcal} \mathrm{kg}^{-1}$ arasında değişmiştir. En yüksek kes SE miktarı 2.95 ve $2.93 \mathrm{Mcal} \mathrm{kg}^{-1}$ ile EZ-6 ve EZ-3'de, en düşük kes SE miktarı $2.81 \mathrm{Mcal} \mathrm{kg}^{-1}$ ile EZ-1'de tespit edilmiştir.

En yüksek kes SE miktarı 2.91 Mcal kg-1 ile Özkaynak çeşidinde, en düşük kes SE miktarı ise 2.86, 2.86 ve 2.87 Mcal kg-1 ile sırasıyla Gap Pembesi, Kirazlı ve Taşkent çeşitlerinde tespit edilmiştir.

Yıl, ekim zamanı ve çeşit birlikte etkileri sonucu kes SE miktarları $2.77 \mathrm{Mcal} \mathrm{kg}^{-1}$ ile $3.30 \mathrm{Mcal} \mathrm{kg}^{-1}$ arasında değişmiştir. En yüksek kes SE miktarı $3.30 \mathrm{Mcal} \mathrm{kg}^{-1}$ ile 2019 yılında sonbaharda 3. ekim (EZ-6) olarak ekilen Özkaynak çeşidinde, en düşük kes SE miktarı $2.77 \mathrm{Mcal} \mathrm{kg}^{-1}$ ile 2019 yılında ilkbaharda 1. ekim zamanı (EZ-1)'nda ekilen Gap Pembesi ve Kirazlı çeşitlerinde tespit edilmiştir.

\section{Kes ME Miktart}

Kes ME miktarı üzerine yılların etkisi önemli olmamıştır. Araştırmanın birinci yılındaki (2018 yııı) kes ME miktarı 2.36 Mcal kg ${ }^{-1}$, ikinci yıldaki (2019 yılı) kes ME miktarı $2.37 \mathrm{Mcal} \mathrm{kg}^{-1}$ olmuştur (Çizelge 6).

Ekim zamanlarına göre kes ME miktarı $2.31 \mathrm{Mcal} \mathrm{kg}^{-1}$ ile $2.43 \mathrm{Mcal} \mathrm{kg}^{-1}$ arasında değişmiştir. En yüksek kes ME miktarı 2.43 Mcal kg-1 ile EZ-6'da, en düşük kes ME miktarı $2.31 \mathrm{Mcal} \mathrm{kg}^{-1}$ ile EZ-1'de tespit edilmiştir.

En yüksek kes ME miktarı $2.39 \mathrm{Mcal} \mathrm{kg}^{-1}$ ile Özkaynak çeşidinde, en düşük kes ME miktarı ise 2.35, 2.35 ve 2.36 Mcal kg ${ }^{-1}$ ile sırasıyla Gap Pembesi, Kirazlı ve Taşkent çeşitlerinde tespit edilmiştir.

Yıl, ekim zamanı ve çeşit birlikte etkileri sonucu kes ME miktarları $2.27 \mathrm{Mcal} \mathrm{kg}^{-1}$ ile $2.70 \mathrm{Mcal} \mathrm{kg}^{-1}$ arasında değişmiştir. En yüksek kes ME miktarı $2.70 \mathrm{Mcal} \mathrm{kg}^{-1}$ ile 2019 yılında sonbaharda 3. ekim (EZ-6) olarak ekilen Özkaynak çeşidinde, en düşük kes ME miktarı 2.27 Mcal kg-1 ile 2019 yılında ilkbaharda 1. ekim zamanı (EZ-1)'nda ekilen Gap pembesi çeşidinde tespit edilmiş̧ir.

Çizelge 6. Yıl, Ekim zamanı ve çeşitlere göre yem bezelyesinin kes SE oranı ve kes ME oranı. Table 6. Straw DE ratio and straw ME ratio of forage pea according to year, sowing time and varieties.

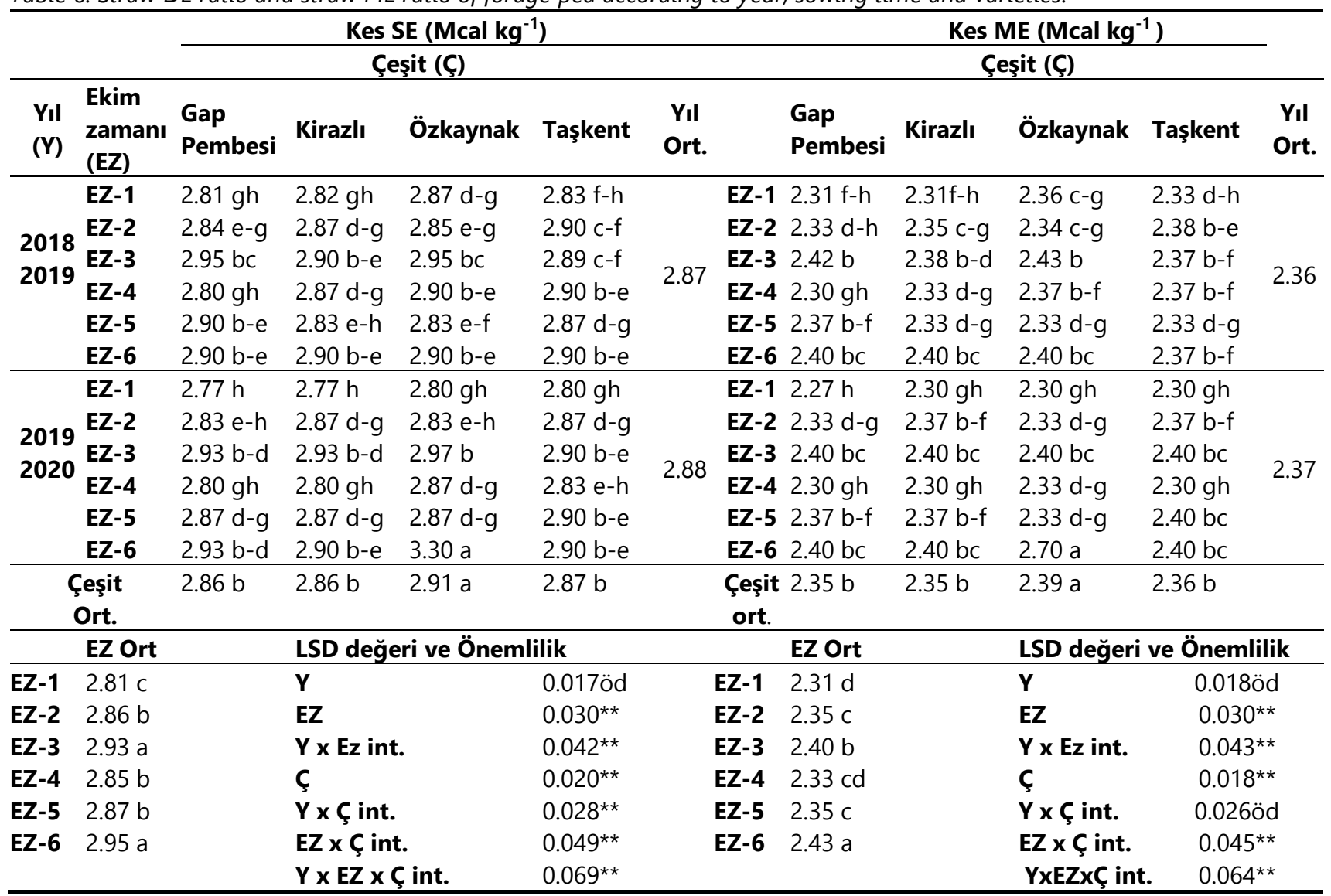

EZ-1: Mart başında, EZ-2: Mart sonunda, EZ-3: Nisan başında, EZ-4: Ekim sonu, EZ-5: Kasım başı, EZ-6: Kasım sonu, öd: önemli değil, **: p>0.01, *: $p>0.05$, aynı harflerle gösterilen veriler arasında fark istatistiksel olarak önemli değildir. 


\section{Kes NYD Değeri}

Yılara göre yem bezelyesi kes NYD değeri önemli bir değişim olmamıştır. Denemenin birinci yılında (2018 yılı) kes NYD değeri 105.5, ikinci yılında (2019 yılı) ise kes NYD değeri 106.7 olarak gerçekleşmiştir (Çizelge 7).

Ekim zamanlarına göre kes NYD değerleri 100.7 ile 115.3 arasında değişmiştir. Ekim zamanlarına göre kes NYD değerinde önemli değişimler olmuştur. Sonbaharda ekimi (EZ-4, EZ-5 ve EZ-6) yapılan yem bezelyelerinin kes NYD değerleri, ilkbaharda ekimi (EZ-1, EZ-2 ve EZ-3) yapılan kes NYD değerlerinden daha düşük olmuştur. En yüksek kes NYD değeri 115.3 ve 110.9 ile sırasıyla Nisan ayı başında (EZ-3) ve Mart ayı sonunda (EZ-2) ekilen yem bezelyelerinde, en düşük kes NYD değeri ise 100.7 ile sonbaharda Kasım ayı başında (EZ-5) ekilen yem bezelyelerinde tespit edilmiştir.

Araştırmada kullanılan çeşitlerin kes NYD değeri 102.0 ile 108.9 arasında değişmiştir. En yüksek kes NYD değeri 108.9 ile Özkaynak çeşidinde, en düşük kes NYD değeri ise 102.0 ile Kirazlı çeşidinde belirlenmiştir.

Yıl, ekim zamanı ve çeşit interaksiyonuna göre kes NYD değerleri 89.7 ile 127 arasında değişmiştir. En yüksek kes NYD değeri 127.0 ile 2019 yılında Özkaynak çeşidinin Kasım ayı sonunda (EZ-6) ekilmesiyle, en düşük kes NYD değeri ise 89.7 ile 2018 yılında Ekim ayını sonunda (EZ-4) ekilen Kirazı ıç̧̧idinde tespit edilmiştir.

Yapılan bir araştırmada yem bezelyesi kes NYD değeri yıllara ve çeşitlere göre önemli derecede etkilenmiştir. Yem bezelyesi çeşitlerinin kes NYD değeri 105.5 ile 147.2 arasında değiştiği tespit edilmiştir (Çaçan ve ark., 2018).

Çizelge 7. Yıl, Ekim zamanı ve çeşitlere göre yem bezelyesinin kes NYD değeri.

Table 7. Straw RFV value of forage pea by year, sowing time and varieties.

\begin{tabular}{|c|c|c|c|c|c|c|}
\hline \multicolumn{7}{|c|}{ Kes NYD } \\
\hline \multirow{2}{*}{$\begin{array}{l}\text { YII } \\
(Y)\end{array}$} & \multirow{2}{*}{$\begin{array}{l}\text { Ekim zamanı } \\
\text { (EZ) }\end{array}$} & \multicolumn{4}{|c|}{ Çeşit (Ç) } & \multirow[b]{2}{*}{ Yıl Ort. } \\
\hline & & Gap Pembesi & Kirazlı & Özkaynak & Taşkent & \\
\hline \multirow{6}{*}{$\begin{array}{l}2018- \\
2019\end{array}$} & EZ-1 & $102.1 \mathrm{j}-\mathrm{o}$ & 106.9 h-m & 112.8 e-h & $112.1 \mathrm{e}-\mathrm{h}$ & \multirow{6}{*}{105.5} \\
\hline & EZ-2 & $116.6 \mathrm{c}-\mathrm{g}$ & $116.8 c-f$ & $113.0 \mathrm{~d}-\mathrm{h}$ & $112.5 \mathrm{e}-\mathrm{h}$ & \\
\hline & EZ-3 & $122.2 \mathrm{a}-\mathrm{c}$ & 111.3 e- & $125.8 \mathrm{ab}$ & $118.1 \mathrm{~b}-\mathrm{e}$ & \\
\hline & EZ-4 & $101.2 k-p$ & $89.7 r$ & $95.3 n-r$ & 111.3 e- e & \\
\hline & EZ-5 & $101.9 \mathrm{k}-\mathrm{o}$ & $93.8 p-r$ & 95.1 o-r & $93.4 p-r$ & \\
\hline & EZ-6 & 94.5 o-r & $99.3 \mathrm{~m}-\mathrm{q}$ & $93.5 p-r$ & $91.8 \mathrm{qr}$ & \\
\hline \multirow{8}{*}{$\begin{array}{l}2019- \\
2020\end{array}$} & EZ-1 & $100.0 \mathrm{~m}-\mathrm{p}$ & $91.0 r$ & 110.3 e-I & $108.3 \mathrm{~h}-\mathrm{I}$ & \multirow{6}{*}{106.7} \\
\hline & EZ-2 & $109.1 \mathrm{f}-\mathrm{k}$ & $110.1 \mathrm{e}-\mathrm{j}$ & $103.6 \mathrm{I-m}$ & $106.0 \mathrm{~h}-\mathrm{m}$ & \\
\hline & EZ-3 & $112.3 \mathrm{e}-\mathrm{h}$ & $100.91-p$ & 121.0 a-d & 110.6 e-I & \\
\hline & EZ-4 & $100.9 \mathrm{I-p}$ & 95.2 o-r & 105.4 h-m & 110.2 e-I & \\
\hline & EZ-5 & $108.7 \mathrm{~g}-1$ & $105.9 \mathrm{~h}-\mathrm{m}$ & $103.4 \mathrm{I-n}$ & $103.3 \mathrm{I-n}$ & \\
\hline & EZ-6 & $108.4 \mathrm{~h}-\mathrm{I}$ & 103.5 I-m & $127.0 \mathrm{a}$ & $105.6 \mathrm{~h}-\mathrm{m}$ & \\
\hline & Çeşit Ort. & $106.5 \mathrm{~b}$ & $102.0 \mathrm{c}$ & $108.9 \mathrm{a}$ & $106.9 \mathrm{ab}$ & \\
\hline & \multicolumn{2}{|l|}{ EZ Ort } & \multicolumn{3}{|c|}{ LSD değeri ve Önemlilik } & \\
\hline EZ-1 & $105.4 \mathrm{~b}$ & & $\mathbf{Y}$ & & 2.69öd & \\
\hline EZ-2 & $110.9 a$ & & EZ & & $4.67^{\star \star}$ & \\
\hline EZ-3 & $115.3 \mathrm{a}$ & & Y x Ez int. & & $6.60^{* *}$ & \\
\hline EZ-4 & $101.2 \mathrm{bc}$ & & Ç & & $2.31 * \star$ & \\
\hline EZ-5 & $100.7 \mathrm{c}$ & & $\mathbf{Y} \times C ̧$ int. & & $3.27^{\star *}$ & \\
\hline \multirow[t]{2}{*}{ EZ-6 } & \multirow[t]{2}{*}{$102.9 \mathrm{bc}$} & & \multirow{2}{*}{\multicolumn{2}{|c|}{$\begin{array}{l}\text { EZ x Ç int. } \\
\text { Y x EZ x Ç int. }\end{array}$}} & $5.67^{\star \star}$ & \\
\hline & & & & & $8.02^{* \star}$ & \\
\hline
\end{tabular}

EZ-1: Mart başında, EZ-2: Mart sonunda, EZ-3: Nisan başında, EZ-4: Ekim sonu, EZ-5: Kasım başı, EZ-6: Kasım sonu, öd: önemli değil, **: p>0.01, *: $p>0.05$, aynı harflerle gösterilen veriler arasında fark istatistiksel olarak önemli değildir.

\section{SONUÇ}

Bu araştırmada, lğdır ekolojik şartlarında 2018 ve 2019 yıllarında 6 ekim zamanında tohum amacıyla yetiştirilen 4 yem bezelyesinin tohum ve keslarının kalite özellikleri incelenmiştir. Ekim zamanları tüm incelenen kalite özelliklerini önemli derecede etkilenmiştir. Illkbahar ekimlerinde tohum ham protein oranı, kes ham protein oranı, kes kuru madde tüketimi, nispi yem değeri sonbahar ekimlerine göre daha yüksek olmuştur. Ayrıca ilkbahar ekimlerinde NDF değerlerinin de düşük olmasıyla ilkbahar kes kalite özelliklerinin sonbahar ekimlerine göre daha yüksek olduğu görülmüştür. Bitkide tohum HP oranı, kes HP oranı, kes NDF oranı, kes ADF oranı, kes KMT oranı ve kes NYD değeri Nisan ayı başındaki (EZ-3) ekimlerde, kes KMS oranı ve kes ME değeri ve kes SE değeri Kasım ayı sonundaki (EZ-6) ekimlerde kalite yönleriyle diğer ekim zamanlarına göre daha iyi sonuçlar elde edilmiştir. Incelenen tüm kalite özellikler yem bezelyesi çeşitlerine göre önemli derecede farklılıklar göstermiş̧ir. Kes NDF oranı ve kes KMT oranı Taşkent, Özkaynak ve Gap Pembesi çeşitlerinde, tohum HP oranı, kes HP oranı, kes ADF 
oranı, kes KMS oranı, kes SE değeri, kes ME değeri ve kes NYD değeri Özkaynak çeşidinde en iyi kalite değerlerine ulaşmıştır.

Sonuç olarak bölge şartlarında tohum ve kes yem kalite özellikleri yönünden Özkaynak çeşidinin daha yüksek değerlerde olduğu belirlenmiştir. Ayrıca Nisan başında ekilen bitkilerde kes yem kalitesinin daha yüksek olduğu ortaya çıkmıştır.

\section{TEŞEKKÜR}

Bu araştırma 2019-FBE-A26 nolu proje olarak Iğdır Üniversitesi Bilimsel Araştırma Projeleri Koordinasyon Birimi tarafından desteklenerek yürütülmüştür.

\section{ÇIKAR ÇATIŞMASI}

Yazarlar herhangi bir çıkar çatışması olmadığını beyan ederler.

\section{YAZAR KATKISI}

Yazarlar makaleye eşit oranda katkı sağlamışlardır.

\section{KAYNAKLAR}

Acar, Z., \& Ayan, i. (2012). Yem Bitkileri Kültürü. Ondokuz Mayıs Üniversitesi, Ziraat Fakültesi Ders Kitabı No: 2.

Açıkgöz, E. (2001). Yem Bitkileri. Uludağ Üniversitesi, Ziraat Fakültesi Tarla Bitkileri Bölümü, Uludağ Üniversitesi Güçlendirme Vakfı, No: 182.

Akyıldız, A. R. (1984). Yemler Bilgisi ve Laboratuar Kılavuzu. Ankara Üniversitesi Ziraat Fakültesi Yayınları. Yayın No: 895, Ankara.

Anonim. (2020). T.C. Tarım ve Orman Bakanlığı Meteoroloji Genel Müdürlüğü.

Avcıoğlu, R., Hatipoğlu, R., \& Karadağ, Y. (2009). Yembitkileri Baklagil Yembitkileri Cilt II, T.C. Tarım ve Köyişleri Bakanlığı Tarımsal Üretim ve Geliştirme Genel Müdürlüğü, İzmir.

Çaçan, E., Kaplan, M., Kökten, K., \& Tutar, H. (2018). Evaluation of some forage pea (Pisum sativum ssp. arvense L.) lines and cultivars in terms of seed yield and straw quality. Iğdır Üniversitesi Fen Bilimleri Enstitü Dergisi, 8(2), 275-284.

Fonnesbeck, P. V., Clark, D. H., Garret, W. N., \& Speth, C. F. (1984). Predicting energy utilization from alfalfa hay from the western region. Animal Science, (Western Section) 35, 305-308.

Ileri, O., Erkovan, Ş., Erkovan, H. İ., \& Ko., A. (2020). İ̧ Anadolu'da İkinci Ürün Döneminde Yem Bezelyesi ve Bazı Tahıl Karışımlarının Farklı Ekim Sıklığında Yaş Ot Verimi ve Bazı Özellikleri. Uluslararası Tarım ve Yaban Hayatı Bilimleri Dergisi, 6(3): 538-545.

Kacar, B., \& İnal, A. (2008). Bitki Analizleri. Nobel Yayınları, Nobel Yayın Dağıtım Ltd. Şti. Yayın No: 1241, Fen Bilimleri, 892. Ankara.

Kadıoğlu, S., \& Tan, M., (2018). Erzurum şartlarında farklı tarihlerde kışık ekilen yem bezelyesi çeşitlerinin verim ve bazı özellikleri. Tarla Bitkileri Merkez Araştırma Enstitüsü Dergisi, 27, 25-32.

Kaplan, M., Kökten, K., Arslan, M., Özdemir S., \& Seydoşoğlu, S. (2014). Farklı yem bezelyesi (Pisum arvense) genotiplerinin tanelerinin yem içeriği yönünden karşılaştırılması, 5th Seed Congress, Diyarbakır.

Khalii, J. K., Sawaya, W. N., \& Hyder, S. Z. (1986). Nutrient composition of atriplex leaves grown in Saudi Arabia. J. Range Manage. 39, 104-107.

Manga, i., Acar, Z., \& Ayan, i. (2003). Baklagil Yem Bitkileri. Ondokuz Mayıs Üniversitesi, Ziraat Fakültesi, Ders Kitabı No: 7, Samsun.

Mukherjee, D., Sharma, B. R., \& Mani, J. K. (2013). Influence of different sowing dates and cultivars on growth, yield and disease incidence in garden pea (Pisum sativum) under mid hill stuation. Indian Journal of Agricultural Sciences, 83, 918-923.

Shaukat, S. A., Ahmad, Z., Chodry, Y. A., \& Shaukat, S. K. (2012). Effect of different sowing dates and row spacing on then growth, seed yield and quality of off-season pea (Pisum sativum L. Cv. Climax) under temperate conditions of Rawalakot Azad Jammu and Kashmir. Scientific Journal of Agricultural, 1, 117-125. 
Sheaffer, C. C., Peterson, M. A., Mccalin, M., Volene, J. J., Cherney, J. H., Johnson, K. D., Woodward, W. T., \& Viands, D. R. (1995). Acide Detergent Fiber, Neutral Detergent Fiber Concentration and Relative Feed Value. North American Alfalfa Improvemnt Conference, Minneapolis.

Sheaffer, C. C., \& Moncada, K. M. (2012). Introduction to Agronomy - Food, Crops and Environment. 2nd ed. 704 p. Delmar, Clifton Park, NY.

Tan, M., Koç, A., Dumlu Gül, Z., Elkoca, E., \& Gül, İ. (2013). Determination of dry matter yield and yield components of local forage pea (Pisum sativum spp. arvense L.) ecotypes. Journal of Agricultural Sciences. 19, 289-296.

Tekeli, A.S., \& Ates, E. (2003). Yield and its components in field pea (Pisum arvense L.) lines. Journal of Central European Agriculture. 4, 313-317.

TÜiK. (2018). Türkiye İstatistik Kurumu. https://data.tuik.gov.tr/Bulten/Index?p=Bitkisel-Uretim-Istatistikleri-2018-27635. Erişim tarihi: 04 Nisan 2021.

Uzun, A., \& Acikgoz, E. (1998). Effect of sowing season and seedling rate on the morphological traits and yield in pea cultivars of differing leaf types. Journal of Agronomy and Crop Science, 181, 215-222.

Uzun, A., Gün, H., \& Açıkgöz, E. (2012). Farklı gelişme dönemlerinde biçilen bazı yem bezelyesi (Pisum sativum L.) çeşitlerinin ot, tohum ve ham protein verimlerinin belirlenmesi. Uludağ Üniversitesi Ziraat Fakültesi Dergisi, 26(1), 27-38.

Van Soest, P. J., Robertson, J. D., \& Lewis, B. A. (1991). Methods For Diatery Fibre, Neutral Detergent Fibre And Non-Starch Polysaccharides İn Relation To Animals Nutrition. Journal of Dairy Science, 74, 3583-3597.

Yıldız, N., \& Bircan, H. (1991). Araştırma ve deneme Metodları. Atatürk Üniversitesi Yayınları No: 697, Ziraat Fakültesi No: 305, Erzurum. 